DOI: https://doi.org/10.31539/leea.v2i1.344

\title{
INDONESIAN EFL STUDENTS’ LEARNING STYLES
}

\author{
Nostalgianti Citra Prystiananta ${ }^{1}$ \\ IKIP PGRI JEMBER \\ prystiananta@gmail.com ${ }^{1}$ \\ Submit, 23-09-2018 Accepted, 21-12-2018 Publish, 21-12-2018
}

\begin{abstract}
This research aims at investigating students' learning styles of Accounting Program of AAK PGRI Jember in learning English as Foreign Language. EFL students have their own ways in learning English which they think as the most enjoyable way to a better comprehension of the material. By investigating their learning styles in learning English, teachers may know the best ways to treat their students to reach a better improvement. In this research, the sample was 41 students from three different academic years who were learning EFL. The data were collected through questionnaire and interview. The questionnaire contained 30 items of statements about 6 learning styles according to questionnaire by Reid (1987). An open-ended interview was conducted to support quantitative data gained from questionnaires. The result presents that students of Accounting Program of AAK PGRI Jember most preferred Visual style (44\%) as their style in learning English. And Individual style (4\%) as the least preferred style. It can be concluded that students of Accounting Program of AAK PGRI Jember enjoy learning English best by the assistance of pictures, charts, and videos because they can comprehend the material better. They also did not enjoy to learn individually because they were not independent type of student who enjoy being alone.
\end{abstract}

Keywords: TEFL, language learning styles

\section{INTRODUCTION}

Naturally, students are human who have their uniqueness. As Chomsky (1966:12) stated that a child may have a generative ability descended by parents' gene. It means that a child has already equipped by some abilities, not just a blank space. However, humans still have different capacities in learning languages (Gleitman, 1993:13). They may also reach different result after learning. The result may be satisfying or, on the contrary, may be disappointing.

There are a lot of possibilities of those problems in regard to students' academic performance. The problems may derive from the approach towards 
communication, learning facilities, proper guidance, and family stress (Mushtaq \& Khan, 2012:18). All three factors such as communication, learning facilities and proper guidance have positive relationship with students' academic performance meanwhile family stress has a negative relationship.

Teaching methods, teachers' competence and performance are not merely to be blamed. Students also have distinct learning strategies and styles which may determine their success. Variants researches have been conducted correspond to language learning styles in English as a Second Language (ESL) and English as Foreign Language (ELF) teaching (Oxford, 2003; Reid, 1987; Muniandy \& Shuib, 2016). The results presented some findings such as some factors which influence the students' ability to learn in a particular framework; different learning style of native speakers and non native speakers which influenced by backgrounds such as sex, length of time, length of studying English, field of study, level of education, TOEFL score, and age; and the most preferred learning styles among students.

Students have variants ways of understanding and learning something on their own. In receiving information or knowledge, it is their right to have the best ways which make them comfortable to learn. Most students have a preferred learning style, depending on the situation and the type of information the student is dealing with (The Department of Education for Newfoundland and Labrador, 2014:34). Some experiences and prior knowledge background may create the distinction of learning styles among students as EFL learners. Some students are easier to learn if they see the pictures (visual style). Some are comfortable in listening information (audio style). Some others are easier to learn through their body movement (kinesthetic style). Some students also enjoy experimenting something to improve a better understanding (tactic style) (Featherstone, 2014; Ghafoor-Davis, 2011).

Learning EFL may be sufficient enough for those who have experiences and prior knowledge about target language. On the other hands, those who are lack of those experiences and prior knowledge tend to face some difficulties. This case may happen to students of non English study program that are lack of English knowledge in which it happens to some countries with English as foreign language or English as second language. Therefore, the investigation of students' of non English Program may assist them to identify what styles appropriate for them. English instructors also should know the combinations of students learning styles as well natural learning needs of their problems (Prashing, 2006:51). 


\section{LITERATURE REVIEW}

\section{English as Foreign Language in Indonesia}

English is an international language used in many countries in the world. There are numbers of English varieties such as British, American, Singapore, Indian, Australian, East African, etc. Why English has to be widely used as international language? According to Maxom (2009:1), there are some factors such as, 1) the political factor gives the current dominance of the USA, 2) science and technology have developed with English as medium of instruction, 3) there is a need for a global language to make international communications smoother, and tools such as the world wide web truly accessible around the planet.

In the use of English, there are two kinds of English varieties according to geographical distinction: those of first language situations where English is the mother tongue (MT), as in the USA or Australia, and second language (SL) situations, where English is the language of commercial, administrative and educational institutions, as in Ghana or Singapore (Broughton, Brumfit, Flavell, Hill \& Pincas, 2003:4).

What about Indonesia? Indonesia as one of countries located in south-east Asia has a large numbers of languages used by different tribes in its archipelago. Indonesians speak at least one native language and more than two second languages. By looking at the situation, English status is as Foreign language that many people do not familiar with.

Introducing and teaching English in Indonesia, formerly, were opposed by Indonesian government in 1950s due to anti-western policy. It caused the English language program declined in educational system in Indonesia (Candraningrum, 2008:51). Yet Sadtono (as cited in Chesire, 1999:325) shows from historical evidence how the status of English has progressed from just one of those foreign languages into the first foreign language. Even so, English cannot replace the primary function of Indonesian language in Indonesia because it has already met a demand of communication in many domains. It is supported also by Lowenberg (as cited in Dewi, 2014:61) who mentioned that English does not strongly function as a second language yet it is a productive language use source for Indonesians.

\section{Teaching English as Foreign Language (TEFL)}

TEFL refers to teaching English activity to students with English as their foreign language. English is the language which is used for only certain purposes and not widely used since they have their first and second language to communicate daily. The fact shows that more than half the world's young children speak two or more 
languages outside school and many millions are now learning English in schools (Dunn, 2014:10-11).

Facing this phenomenon, English instructors or teachers must handle some difficult situation in TEFL due to limited knowledge of English. Because English is not a primary language spoken by students, the first thing to do is get them familiar with English.

Some efforts had been conducted such as applying TEFL in pre-schools and primary schools. Even though they are not a compulsory course, English is better to introduced in the early ages. It happens in China in which English is considered one of three major subjects in middle schools and in some primary schools (Keqiang, 1986:155). China even collaborates with some English speaking countries such as Canada and United States. One of the short program is summer teaching program in China Universities cooperates with American Universities which is promoted through some websites including teach-english-in-china.co.uk and mdtesol.org.

The efforts in TEFL indicate a lot of improvement and progress presented by many experts in the world. Students are one of many important terms in teaching and learning activities. If students show their positive progress, then teaching is successfully conducted. On the contrary, if students show a negative progress such as achieving bad scores and bad skills improvement, teaching has to be evaluated more. Students may be tired of the material. Students are also possible to have different learning strategies and styles.

Identifying and analyzing students' learning style in English is important to support the success of TEFL. By doing some investigation, teachers will know the difference among students which cause different result in the classroom. Through the analysis, teachers can evaluate teaching and learning process to reach a better goal in TEFL.

\section{Learning Styles}

Humans live in different ways. It happens also in the way they learn something. They may choose the ways which make them comfortable to assist their understanding toward something. The learning styles may vary both among individuals and groups.

Learning style refers to the way a person absorbs and retains information and skills (Cox, Sproles \& Sproles, 1988:7). The different styles may be characterized by each individual characteristic which influence them to lean on certain styles.

Some experts have different opinion of classifying language learning styles. According to Willing (as cited in Harmer, 2003:43) in his research, there are 4 types 
of learning styles including convergers (a loner who enjoy being independent and prefer to avoid groups), conformists (a dependent student who are not creative), concrete learners (students who prefer language use and groupwork in class), and communicative learners (a language-use-oriented student).

On the other hands, students' learning style may influenced by circumstances of learning. It is also called a cognitive style which was classified into fielddependent (FD) and field-independent (FI) (Saville-troike, 2006:87). FD is kind of dependent students who enjoy communicate in groups and to other groups and FI is kind of students who enjoy learning alone. The field discriminate learners from their autonomy in learning whether they like to socially communicate or not.

The most well-known learning styles are Visual, Auditory and Kinesthetic (VAK) (Malone, 2003:305). Visual style refers to students who observe pictures; auditory refers to students who listen to sounds; and kinesthetic style requires body movement. Meanwhile, Flemming and Mills (1992:56) insert VAK with R (read/write) into VARK because they believed that there may be style of writing or reading because they are comfortable to learn through writing some notes or reading text. On the other hands, there is tactic style in which students prefer experimenting something rather than just practicing it.

Furthermore, according to Reid (1987:92), there are 6 styles by a research she conducted namely visual, auditory, tactile, kinesthetic, group and individual. For group learners, they enjoy more interaction with classmates while individual likes to study alone without much interaction to others.

However, those classifications of learning styles has similar purpose in teaching, namely, to assist students to learn better by knowing their best ways to comprehend the material. If the learning style causes a negative attitude probably it is teachers' duty to treat students to a better way of learning.

\section{RESEARCH METHOD}

The research is a non-experimental research with survey research design. Survey research was conducted to collect a large data to describe the important phenomena of students' English learning strategies.

The data were collected through questionnaire and interview to gather the data from 41 students from all accounting Program of AAK PGRI Jember. The questionnaire was in the form of close type in which the sample only answered the question by choosing one option in each question. It was Perceptual Learning Style Preference Questionnaire (PLSPQ) by Joy Reid (1984:110). It contained 6 learning styles including visual, auditory, kinesthetic, tactile, group learning and individual 
learning then it translated into Indonesian Language as students' first and second language. Validation was done by expert judgment. The interview was also conducted to support the data gained from questionnaires. The type of interview was open-ended questions to open a possibility for the researcher to ask questions and the sample to answer the questions easily.

The data analysis was conducted through statistical procedure by calculating Means (M),Standard Deviation (SD) and percentage (\%) (Weinberg \& Abramowitz, 2008:95). According to Reid, students were classified into 6 types of learning styles indicated through the score of each item which represented each style. Then the students' score of each item were classified into 6 different styles to find out the most preferred learning styles among all students.

\section{FINDING}

The research was conducting by distributing questionnaire of PLSPQ which was adapted from Reid (1984:110) and translated into Indonesian language. Some statistical procedures were conducted and finally show some results which answer the research questions.

In table 2, there are 6 learning styles preferred by students and the rank presents that most of students preferred visual (44\%) as the most enjoyable way to learn English. The second most preference is kinesthetic (24\%) style which requires body movement or active movement. The last rank which shows the least preferred style is tactile (6\%) and individual (4\%) learning styles.

Table 1. Students' Accounting Program Learning Styles

\begin{tabular}{lcccc}
\hline Learning Style & M & SD & \% & Rank \\
\hline Visual & 3.4927 & 0.5522 & 44 & 1 \\
Tactile & 2.0690 & 0.3271 & 6 & 5 \\
Auditory & 3.0780 & 0.4888 & 10 & 4 \\
Kinesthetic & 3.4048 & 0.5383 & 24 & 2 \\
Group & 3.2927 & 0.5206 & 12 & 3 \\
Individual & 2.0683 & 0.3270 & 4 & 6 \\
\hline
\end{tabular}

\section{Visual Learning Style}

Visual learners are usually preferred to learn by seeing pictures, images, movies, etc. which shows the visualization which attract the eyes (Reid, 1978; Featherstone, 2014; Ghafoor-Davis, 2011). In accounting program of AAK PGRI Jember, students most prefer visual style as their learning style which is indicated 
by $44 \%$. It means there are 18 who chose this style to learn English in the classroom. The statements contain visual style are in statement number 6, 10, 12, 24, and 29.

The statements are: (1) I learn better by reading what the lecturer writes on the whiteboard, (2) when I read instructions, I remember them better, (3) I understand better when I read instruction, (4) I learn better by reading and see pictures then by listening to someone, (5) I learn more by reading textbooks than by listening to lecturers.

For $44 \%$ percent students put good scores to those 5 statements which indicated that their learning style is visual learning style. For example, they enjoy English and easier to remember the material if the lecturer used pictures, charts and videos as media.

\section{Kinesthetic Learning Style}

Kinesthetic learning style is the style that causes a very active teaching and learning. In this case, students who prefer the style may enjoy the class by moving around the classroom and collaborate with friends. It does not mean they love to cooperate, but they like to be more active not only sitting on their seats.

The style surprisingly is at the second rank after visual students' learning style preference. At this level, students preferred kinesthetic style for $24 \%$ of the total sample. The statements contain kinesthetic statements are number 2, 8, 15, 19 and 26. The statements are: (1) I prefer to learn by doing something in class, (2) When I do things in class, I learn better, (3) I enjoy learning in class by doing experiments, (4) I understand things better in class when I participate in role-playings/simulation, (5) I learn best in class when I can participate in related activities.

This style is as the second rank of the most preferred by students in Accounting Program of AAK PGRI Jember. It refers to the style in which students enjoy to do things that move their body in learning. It may be indicated by practicing English by games or cooperative activities. For example, in learning pronunciation in English, it may be fun if they play pronunciation Uno game.

\section{Group Learning Style}

Group learning is the third rank as the most preferred learning style among students of Accounting Program of AAK PGRI Jember. Group learning considers as the effective learning style for those who are not creative enough and have slow response to lecturer's instruction and English material. Five or 12\% students selected 5 questions contain statements about group learning style. The statements are statement number 3, 4, 5, 21 and 23, presented as follow: (1) I get more work done 
when I work with others, (2) I learn more when I study with a group, (3) In class, I learn best when I work with others, (4) I enjoy working on an assignment with two or three classmates, (5) I prefer to study with others.

The students with this learning style are dependent and always discuss to classmates in pair or in a small group to solve the problems or difficulties they have. This learning style may be visible when there are some exercises and projects instructed by the lecturers.

\section{Auditory Learning Style}

Auditory learning style is ranked fourth after group learning style. There were 4 students who prefer this style or $10 \%$ out of 41 students. Most students in this group of learning style are talkative and memory-oriented (Muniandy \& Shuib, 2016:5). They enjoy discussion and listen others a lot. For example, they enjoy listening to English songs to learn vocabularies and pronunciation. They are also comfortable to listen a lecturer's or friend's explanation.

Five items of statements about auditory learning style are item number 1, 7, 9, 17, and 20, as presented as follow: (1) When the lecturer, tells me the instruction I understand better, (2) When someone tells me how to do something in class, I learn it better, (3) I remember things I have heard in class better than things I have read, (4) I learn better in class when the lecturer gives a lecture, (5) I learn better in class when I listen to someone.

The statements above indicate that a student is more comfortable and easier to comprehend the input they receive by listening to someone speaking, and explaining directly or from a recording. In Accounting Program of AAK PGRI Jember, the students who prefer the style were only 4 students. They more understand about English material when the lecturers explain directly in front of the class and easier also to recall the information.

\section{Tactile Learning Style}

This learning style was not too much preferred by Accountant Program students in learning English. Tactile learning style requires students to do some experiments or project works which finally produce something in concrete things. They enjoyed doing class projects such as shooting speaking performance and record it in a video file. They were comfortable to draw words chart or making the chart as creative as possible. But according to the result, only 2 students who prefer this style in learning English (only $6 \%$ ). 
The statements included in this learning style are item number $11,14,16,22$, and 25 presented as follow: (1) I learn more when I make a model of something, (2) I learn more when I make something for a class project, (3) I learn better when I make drawings as I study, (4) When I build something, I remember what I have learned better, (5) I enjoy making something for a class project

From those five statements above comprise ideas which described the students as tactile learners. Five out of 41 students chose this style as they preferred style in learning English. It means the students of Accounting Program of AAK PGRI Jember did not really enjoy making projects or doing some activities creatively in producing something as the learning result. Indeed, tactile learning style is a style which attributes creative, innovative, and enthusiastic learners. Doing some experiments, creating some products or doing simulation are the things that not all students capable of.

\section{Individual Learning Style}

Individual learning style is the opposite learning style of group learning style. If students in group learning style enjoy cooperating and discussing something with friends or classmates, students with individual learning style prefer doing many things alone. They tend to be independent students and love to solve the problems as well as finish the tasks alone. Students with this learning style become the least preferred because only a few students who enjoy of being alone and independent. There were only five students out of 41 students of Accounting Program of AAK PGRI Jember who prefer this style (4\%).

The statements which comprise about individual learning styles are stated in items number 13, 18, 27, 28, and 30 presented as follow: (1) When I study alone, I remember things better, (2) When I work alone, I learn better, (3) In class, I work better when I work alone, (4) I prefer working on projects by myself, (5) I prefer to work by myself.

Students with this learning style enjoy being alone out of crowded places. They cannot concentrate well if they are in noisy situation. They do not cooperate well with others or classmates. They think that they may comprehend the material well if learn and work alone. They also enjoy a self-project comparing to a groupproject. Therefore, this learning style is not good enough to maintain because it may give negative atmosphere in the classroom. If this learning style is the least preferred, it means that the classroom situation is active and enthusiastic. 


\section{DISCUSSION}

Based on statistical procedures in analyzing the data, findings show that most students of Accounting Program of AAK PGRI Jember preferred visual learning style as the way to learn English. It means they comprehend better through the visualization of information they receive. The quantitative data were also supported by interviewing the students. The number of $44 \%$ is a large percentage which indicates more tendencies of students to be visual students. They were comfortable to learn what they can see by their eyes such as by reading the notes, reading at the lecturer's explanation on the whiteboard, and reading and looking at the lecturer's power point presentation which inserted by some visual graphics.

The second most preferred style is kinesthetic style (24\%). It means students in the program enjoy to do some activities in the classroom such as doing exercise on the note book or on the board, discussing with friends, doing role-play and simulation (Malone, 2003, p.306.)The students with this learning style cannot just stay on their seats because it would make them boring and they cannot comprehend the material easily. Therefore, teachers have to think more creatively to give a better learning opportunity to these students.

The third most preferred learning style is group learning styles (12\%). The students in this learning style belong to FD or Field Dependent (see Saville-troike, 2006:87)who are dependent to classmates. They enjoy learning in group or at least a partner. They love to communicate, share ideas, or just like being together with friends not only in the classroom but also outside.

Auditory learning style was the fourth most preferred style in Accounting Program of AAK PGRI Jember (10\%). As Muniandy and Shub (2016:5) stated that auditory learners acquire information by listening and they prefer classroom activities like role-play and discussion. Most of them are talkative and memory-oriented. In the research, it was found out that the students with this learning style were easier to understand the direct oral instruction and lecturer in English. It may be very much beneficial for them to do something immediately and fast forward.

The fifth preferred learning style was tactile $(6 \%)$. Tactile requires students' creative activities such as simulation, doing experiments and finishing projects. According Hayes (2009:413), tactile learning style is almost always associated with kinesthetic learning because both styles involve bodily movement. The statement is contradicted with the finding which showed different rank between both styles. The distinction is caused by the way of using body movement. The students enjoyed learning in the classroom without having projects or experiments but they love to 
move their body around the classroom by practicing and doing the tasks during teaching and learning activity.

The least preferred learning style was individual learning style (4\%). In this learning style students usually prefer doing everything alone. The individual students in Accounting Program ware also stated that they enjoy learning alone in a quiet place. They were not talkative and saying their opinions a lot. There were only 2 students belong to this learning styles probably because most of the students in the program are not individual. They are dependent students who need mates assistance in learning English.

According to the data analysis, some styles disposed to relate each other because the style similarity. The style similarity means the style shows the similarity in some sense such as similar in sense organ location, eyes and ears as in visual and auditory and the activity of using the body to learn as in kinesthetic and tactile.

However, no individual can be said belongs to only one category. The learning style may be different depend on the situation (Rubio, Perez-Paredes, Luque as cited in Megias Rosa, 2008:18). It also happenedto students of Accounting Program of AAK PGRI Jember in which some of them tended to choose some items related to different learning styles. There is some students showed more than one major category of learning style. For example, the score indicated the most preferred style was visual style but they also showed sufficient score to be group style.

\section{CONCLUSION}

Teaching and learning English is a challenge both for students and language instructors. Because English is a foreign language, it is harder for students to learn the language without any prior skills. Moreover, TEFL for students of non-English study program might be more complicated because of the students' interest which is more interested in other disciplines but English. Study about learning style may assist both students and language instructor to overcome some English teaching and learning difficulties, particularly in Accounting Program of AAK PGRI Jember. The information gained from the research presented some findings such as students learning style preference and the rank. Learning style categories are based on Reid classification consist 6 types of learning style. The data analysis showed that visual learning style was $44 \%$ preferred, kinesthetic style was $24 \%$ preferred, group style was $12 \%$ preferred, audio style was $10 \%$, tactile style was $6 \%$ and individual learning style was only $4 \%$ preferred. The finding indicated that the most preferred style in Accounting Program of AAK PGRI Jember was visual learning style (44\%) and individual learning style was the least preferred (4\%). The research is expected 
to contribute in the advance of TEFL in AAK PGRI Jember especially Accounting Program. By knowing about their learning styles, students may improve their English learning in their own ways. Moreover, language instructor must guide their students to adjust their learning styles and teaching as learning situation as well as figuring out the solution in improving their performance.

\section{REFERENCES}

Broughton, G, Brumfit, C, Flavell, R., Hill, P., \& Pincas, A., (2003). Teaching English as a foreign language. New York: Routledge.

Candraningrum, D. (2008). The challenge of teaching English in Indonesian's Muhammadiyah universities (1958-2005). Munster: the Deutsche National bibliothek.

Chesire, J, (1999). English around the world: Sociolinguistic perspective. Cambridge: Cambridge University Press.

Chomsky, N. (1966). Topics in the theory of generative grammar. Netherlands: Mouton\&Co. N. V.

Cox, D. E., Sproles, E. K., \& Sproles, G. B. (1988). Learning style variations between rural and urban students. Research in rural education. 5 (1), 27-31. Retrieved June 10, 2017 from jrre.vmhost.psu.edu/wp-content/uploads/2014/02/51_5.pdf

Dewi, A. (2014). Perception of English: A study of staff and students at university in Yogyakarta, Indonesia. Newcastle: Cambridge Scholars Publishing.

Dunn, O. (2014). Introducing English to Young Children: Spoken language. London: HarperCollins.

Featherstone, S. (2014). Learning to learn. New York: Bloomsburry.

Flemming, N. D. \& Mills, C. (1992). Not another inventory, Rather a catalyst for relfection: To improve the academy. 11, 137-155. Retrieved October 10, 2017 from www.vark-learn.com/wpcontent/uploads/2014/08/not_another_inventory.pdf

Ghafoor-Davis, K. V. (2011). Real talk: Ten parenting strategies to raise confident successful children. Retrieved March 15,2017 from https://books.google.co.id/books?id=zq1OAAAAQBAJ\&pg=PA112\&dq=lan guage+learning+styles+VAK\&hl=en \&sa $=X \& v e d=0 a h U K E w j e m I n B m b L Z A$

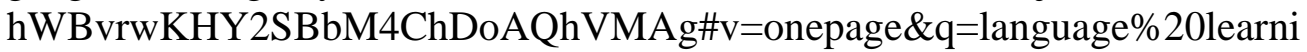
ng\%20styles\%20VAK\&f=false.

Gleitman, L. (1993). A Human Universal: The Capacity to Learn a Language. Modern Philology, 90, S13-S33. Retrieved from http://www.jstor.org/stable/438421.

Harmer, J. (2003). The practice of English language teaching. Essex: Longman.

Keqiang, W. (1986). Teaching English as a Foreign Language in China. TESL Canada journal. 3 (1) . Retrieved September 10, 2017 from citeseerx.ist.psu.edu/viewdoc/download?doi=10.1.1.457.2613\&rep=rep1...pdf 
LeFever, M. (2004). Learning Styles. Colorado Springs: David C. Cook.

Malone, S.A. (2003). Learning about learning. London: CIPD.

Maxom, M., (2009). Teaching English as a foreign language for dummies. West Sussex: John Wiley \& Sons, Ltd.

Megias Rosa, M. (2008). Didactic approach for teachers of English in an international context. Salamanca: Ediciones Universidad De Salamanca.

Muniandy, J. \& Shuib, M. (2016). Learning styles, language learning strategies and fields of study among ESL learners. Malaysian Journal of ELT Research. 12 (1), 1-19. Retrieved February 9, 2017 from https://journals.melta.org.my/index.php/majer/article/viewFile/22/5

Mushtaq, I \& Khan, S. N. (2012). Factors affecting students' academic performance. Global Journal of Management and Business Research. 12 (9), 16-22. Retrieved march 12, 2017 from https://globaljournals.org/GJMBR_Volume12/3-Factors-Affecting-StudentsAcademic.pdf.

Oxford, R. L. (2003). Language learning styles and strategies: an overview. GALA. $\begin{array}{lllll}\text { Retrieved } & \text { September } & 07 & 2017 & \text { from }\end{array}$ web.ntpu.edu.tw/ language/workshop/read2.pdf.

Prashing, B. (2006). Pocket PAL: Learning styles and personalized teaching. London: Network Continuum Education.

Reid, J. M. (1987). The Learning style preference of ESL students. TESOL Quarterly, 21 (1). 87-110. Retrieved September 12, 2018 from old.fltrp.com/download/06071807.pdf

Saville-Troike, M. (2006). Introducing second language acquisition. Cambridge: Cambridge University Press.

The Department of Education for Newfoundland and Labrador. (2014). English language arts kindergarten curriculum cuide. Labrador: Newfoundland Labrador.

Weinberg, S. L. \& Abramowitz, S. K. (2008). Statistics using SPSS: An integrative approach. Cambridge: Cambridge University Press.

Willing, K. (1987). Learning styles in adult migrant education. Sydney: NSW Adult Migrant Education Service 
2018. Linguistic, English Education and Art (LEEA) Journal 2 (1):30-42 